\title{
ClimPlant: Realized climatic niches of vascular plants in European forest understoreys
}

\author{
Pieter Vangansbeke ${ }^{1}$ (D) | František Málišs ${ }^{2}$ (D) | Radim Hédl $^{3}$ (D) | \\ Markéta Chudomelová $^{3}$ (D) | Ondřej Vild ${ }^{3}$ (D) | Monika Wulf ${ }^{4}$ (D) | Ute Jahn ${ }^{4}$ | \\ Erik Welk $^{5}$ (D) | Francisco Rodríguez-Sánchez ${ }^{6,7}$ (D) | Pieter De Frenne ${ }^{1}$ (D)
}

\author{
${ }^{1}$ Forest \& Nature Lab, Department of \\ Environment, Faculty of Bioscience \\ Engineering, Ghent University, Melle- \\ Gontrode, Belgium \\ ${ }^{2}$ Department of Phytology, Faculty of \\ Forestry, Technical University in Zvolen, \\ Zvolen, Slovakia \\ ${ }^{3}$ Department of Vegetation Ecology, \\ Institute of Botany, Czech Academy of \\ Sciences, Brno, Czech Republic \\ ${ }^{4}$ Research Area 2, Leibniz - Centre for \\ Agricultural Landscape Research (ZALF), \\ Müncheberg, Germany \\ ${ }^{5}$ Department of Geobotany and Botanical \\ Garden, Institute for Biology, Martin- \\ Luther-University Halle-Wittenberg, Halle, \\ Germany \\ ${ }^{6}$ Department of Plant Sciences, University of \\ Cambridge, Cambridge, UK \\ ${ }^{7}$ Departamento de Biología Vegetal y \\ Ecología, Universidad de Sevilla, Seville, \\ Spain
}

\section{Correspondence}

Pieter Vangansbeke, Forest \& Nature Lab, Department of Environment, Ghent University, Geraardsbergsesteenweg 267, 9090 Melle-Gontrode, Belgium.

Email: pieter.vangansbeke@ugent.be

\section{Funding information}

Agentúra na Podporu Výskumu a Vývoja, Grant/Award Number: 19-0319; H2020 European Research Council, Grant/Award Number: 757833; Czech Academy of Sciences long-term research development project, Grant/Award Number: RVO 67985939; VI Plan Propio de Investigación of Universidad de Sevilla, Grant/Award Number: VI PPIT - US; Seventh Framework Programme, Grant/Award Number: 275094

Editor: Volker Bahn

\begin{abstract}
Motivation: Detailed knowledge on the climatic tolerances of species is crucial to understand, quantify and predict the impact of climate change on biodiversity and ecosystem functions. However, quantitative data are limited; often, only expert-based qualitative estimates are available. With the ClimPlant database, we capitalize on the link between species distribution ranges and macroclimate to infer the realized climatic niches of 968 European forest plant species.

Main types of variables contained: The ClimPlant database contains information on the distribution of monthly, growing-season and annual mean, minimum and maximum temperature and total precipitation within the distribution range of 968 European forest plants.

Spatial location and grain: Europe in 10 arc-min grid cells; the study area has been cropped rectangularly at $15^{\circ} \mathrm{W}$ (Atlantic Ocean), $60^{\circ} \mathrm{E}$ (Ural Mountains), $25^{\circ} \mathrm{N}$ (Sahara) and $75^{\circ} \mathrm{N}$ (Arctic Ocean).

Time period and grain: The distribution ranges of forest plant species are based on two renowned distribution atlases. The monthly mean, minimum and maximum temperature and precipitation between 1970 and 2000 were extracted from WorldClim v.2.

Major taxa and level of measurement: Nine hundred and sixty-eight vascular plant species of European forests, with taxonomy following the Euro+Med PlantBase nomenclature .

Software format: Data in 56 CSV files, with 1,000 values for monthly, growing season and annual observations of mean, minimum and maximum temperature and precipitation in the distribution range for every species. One summary CSV file with summary statistics (mean, median, fifth and 95th percentile), for every species, of each climatic variable, together with seven key geographical descriptors: area of the distribution range, latitude and longitude of the centroid, and northern, eastern, western and southern range limits within the study area.
\end{abstract}

\section{KEYWORDS}

climate change, distribution range, European temperate forests, forest plants, realized climatic niche, thermal tolerance 


\section{1 | INTRODUCTION}

The climate of the Earth is warming rapidly, pushing plant species to shift their distribution ranges (Chen et al., 2011; Lenoir \& Svenning, 2015). These distribution shifts are changing the composition of plant communities, with potential impacts on ecosystem functioning and services (Pecl et al., 2017). Determining which organisms are most vulnerable to climate change and understanding the impact of recent climate change on biodiversity and ecosystem functioning are important and timely topics of global ecology and biogeography (Broennimann et al., 2006; Urban, 2015).

Temperate forests persist in one of the most populated parts of the globe and are important for biodiversity conservation (Gilliam, 2016). In temperate forests, c. $80 \%$ of the plant diversity can be found at the forest floor (Gilliam, 2007). Nevertheless, our knowledge on the climatic tolerances of vascular plant species, even in intensively studied European temperate forests, remains very limited. The ecological indicator values developed by $\mathrm{H}$. Ellenberg for the Central European flora contain a so-called temperature $(T)$ value associated with species thermal tolerance (Ellenberg \& Leuschner, 2010). This indicator was developed based on a combination of the distribution data range and from local distribution and habitat heat load and is, as such, a hybrid between an ecological site indicator and a biogeographical indicator value (Berg et al., 2017). However, this indicator has important drawbacks: It is a single number per species, with no associated uncertainty and range, which limits its application in statistical models (Bartelheimer \& Poschlod, 2016; Diekmann, 2003). The Ellenberg value also corresponds, in part, to floristic zones and is biased by environmental preferences of listed species in Central Europe and their elevational distributions (see Berg et al., 2017). In addition, it is missing for many European species.

The climatic tolerance of a species is best characterized by its fundamental climatic niche, that is, the theoretical climatic niche space where a species can survive and reproduce (Pearman et al., 2008; Soberón \& Arroyo-Peña, 2017). However, to determine the fundamental climatic niche emperically in field or laboratory conditions would require detailed ecophysiological measurements, experiments and long-term studies and is impractical for a large number of species and climatic dimensions (Peterson et al., 2011). An alternative way to estimate the climatic tolerance of many species is via their distribution range. Indeed, the suite of environments where a species occurs can be used to infer their realized climatic niche, that is, the climatic niche space that is genuinely occupied by a species (Peterson et al., 2011). The realized climatic niche is usually narrower than the fundamental niche because the distribution range is limited not only by climate, but also by habitat preference, biotic interactions, dispersal limitation or other limiting biotic or abiotic factors (Pellissier et al., 2013; Silvertown, 2004). Although imperfect, realized climatic niches as inferred from species distribution ranges are often the only available estimation of the climatic tolerance of a species and have been used extensively in ecological niche modelling for decades (Peterson et al., 2011). The realized climatic niche concept is best applied at large spatio-temporal scales (Schweiger \& Beierkuhnlein, 2016) and when uncertainty in estimated climatic tolerances is considered appropriately (De Frenne et al., 2013; Rodríguez-Sánchez et al., 2012).

Here, we aim to fill a knowledge gap regarding climatic tolerances of European forest plant species and contribute a new dataset to the toolbox of ecologists and biogeographers. We have digitized distribution maps of 968 vascular plant species, covering a large proportion of the vegetation in temperate European forests. By combining the distribution ranges with spatial data on temperature and precipitation, we provide quantitative profiles of the climatic conditions occupied by each species as estimates of their realized climatic niches. We hereby make these data open and available as the ClimPlant database. These data can aid ecologists to evaluate climate change impacts in European forests, to understand better the biotic responses at the species and community levels and to answer important fundamental ecological questions. The dataset has been used previously in several assessments of climate-driven changes in European forest plant communities (De Frenne et al., 2013, 2015; Staude et al., 2020; Zellweger et al., 2020).

\section{2 | MATERIALS AND METHODS}

We obtained the distribution maps from two renowned atlases of Hultén and Fries (1986) (584 species) and Meusel et al. (1965, 1978) and Meusel and Jäger (1992) (384 species). The expert maps of the natural distributions in these atlases are based on a synthesis of accumulated regional fieldwork data. We focused on species that occur in forestREplot (www.forestREplot.ugent.be), an extensive database of $>4,000$ temperate forest resurvey plots spread across Europe, capturing a large part of the plant diversity of European temperate forests. For studies using the forestREplot database, see Baeten et al. (2014); Bernhardt-Römermann et al. (2015), Staude et al. (2020), Verheyen et al. (2012) and Zellweger et al. (2020). We included herbaceous and woody species of forest understoreys, but excluded bryophytes. In total, we digitized distribution maps of 968 species [following the Euro+Med PlantBase nomenclature (Euro+Med, 2006); Supporting Information Table S1], which represent $93.9 \%$ of the estimated vegetation cover in the plots of the database. The ClimPlant database thus holds information for the vast majority of understorey plants in the forestREplot database, which is an extensive sample of temperate European forests.

The scanned maps were georeferenced using Quantum GIS (QGIS Development Team, 2020) with a thin-plate transformation and a nearest-neighbour resampling method (Figure 1a) (De Frenne et al., 2013). The monthly mean, minimum and maximum temperature and precipitation data were based on the mean of the 19702000 period and were downloaded from WorldClim v. 2 as a raster file with 10 arc-min resolution (Fick \& Hijmans, 2017). Forest microclimates vary at extremely small scales across space and time, mostly driven by changes in canopy cover (De Frenne et al., 2019; Maclean, 2020; Zellweger et al., 2019). Hence, Worldclim spatial 
FIGURE 1 (a) Map of the study area, with digitized distribution ranges of three example species: Trientalis europaea (blue), Polygonatum multiflorum (green) and Ruscus aculeatus (red). The map was made with QGIS (QGIS Development Team, 2020). (b) Density plots of the mean 1970-2000 May temperature within the distribution range of the same three species. For P. multiflorum, we also plotted the minimum (dotted line) and maximum (dashed line) May temperature within the distribution range. [Colour figure can be viewed at wileyonlinelibrary.com]
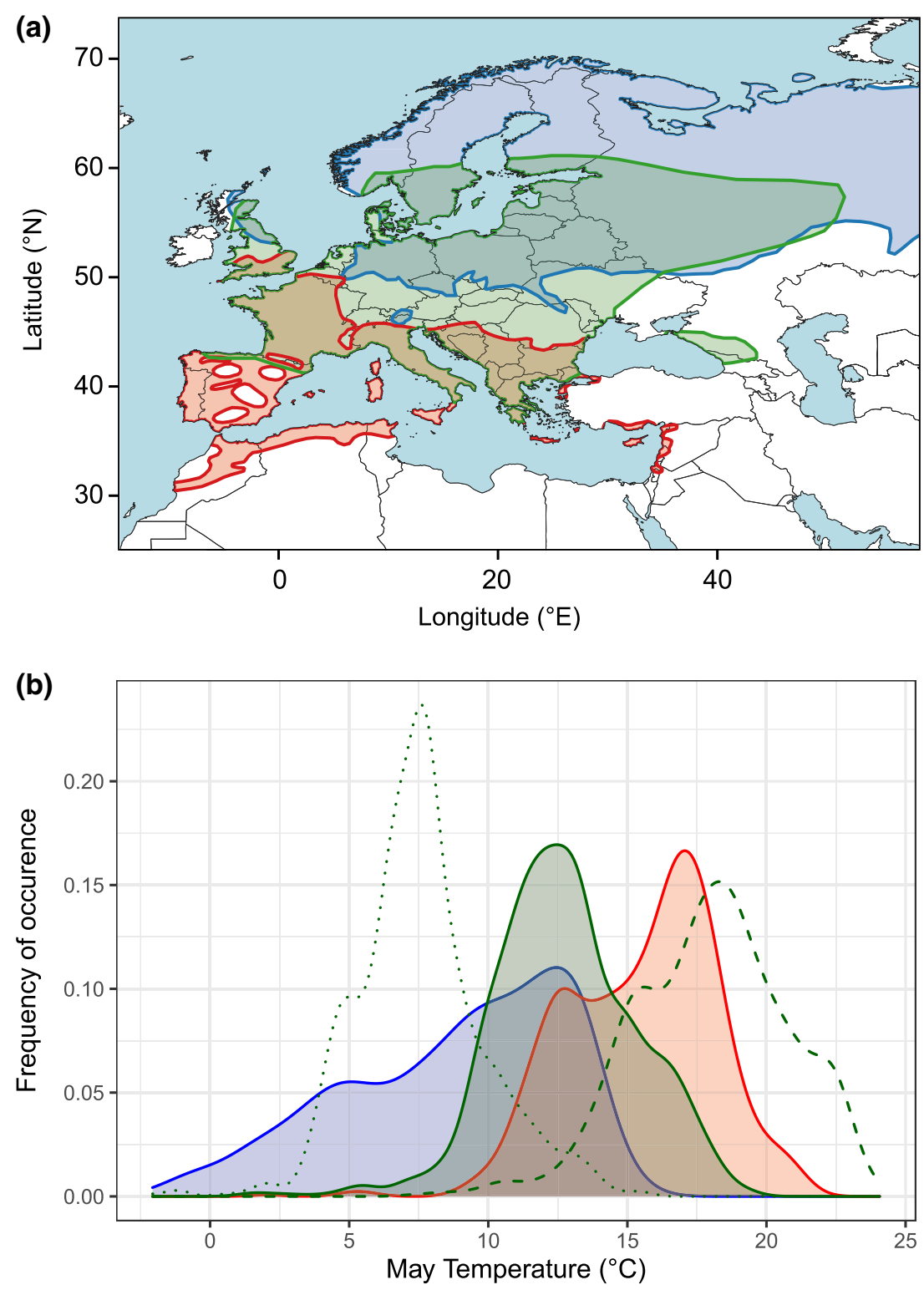

resolution is still coarse to represent the real climatic conditions experienced by these plants in the field, especially in forests. However, high-resolution European microclimate maps are not yet available. Moreover, using smaller grid cells for the climatic data is not useful, because the resolution of the scanned distribution maps itself is also a limiting spatial factor.

To estimate the realized climatic niche of each species, we set the study area extent to all land between $15^{\circ} \mathrm{W}$ (Atlantic Ocean) and $60^{\circ} \mathrm{E}$ (Ural Mountains) and between $25^{\circ} \mathrm{N}$ (Sahara) and $75^{\circ} \mathrm{N}$ (Arctic Ocean), comprising a total of 22,650 grid cells of $20 \mathrm{~km} \times 20 \mathrm{~km}$. We selected four climatic variables (mean, maximum and minimum temperature and precipitation) for 14 different time periods (for every month, for the whole year and for the growing season defined as April-September) to obtain 56 combinations. For each species, we sampled 1,000 grid cells randomly, with replacement, within the species distribution range for every climatic variable and time period (Figure $1 \mathrm{~b}$ ). For 66 species (6.82\% of the total species pool), the distribution range was $<1,000$ grid squares. To generate consistent data series for all species (1,000 values), we used random sampling with replacement instead of a random sample or all grid squares, thus obtaining 56 data files with 1,000 observations for each of the 968 species. From these, we also extracted a summary file with key statistics (mean, median, fifth and 95th percentiles) of growing-season and yearly climatic values for every species, complemented by seven geographical parameters: Area of the distribution range, latitude and longitude of the centroid, and northern, eastern, western and southern range limits within the study area. All analyses were performed in R v.3.6.3 (R Core Team, 2020).

\section{3 | RESULTS}

The data contained in the ClimPlant database allow ecologists and biogeographers easily to obtain detailed quantitative estimates of the realized climatic niche of 968 European temperate forest species. The database covers a wide phylogenetic range (98 families 
represented; 20 families with $\geq 15$ species; Supporting Information Table S2). Importantly, ClimPlant provides the full distribution of climatic values for each species, hence enabling researchers to consider intraspecific variation and propagate uncertainty in the realized climatic niches (Rodríguez-Sánchez et al., 2012). Key summary statistics, such as mean annual temperature, annual precipitation and centroids of the distribution range within the study area, are also readily available for every species (Figure 2).

Of the 968 species contained in the ClimPlant database, fewer than half (46\%) had Ellenberg T-values available; therefore, ClimPlant provides much-needed information on climatic tolerances for 523 new species. For the 445 species having Ellenberg T-values (Ellenberg \& Leuschner, 2010), we found a clear relationship between these and the mean annual temperature within the distribution range, albeit with a large variation $\left(p<.01, R^{2}=.22\right.$; Supporting Information Figure S1). As mentioned earlier, the Ellenberg $T$-values lack the intraspecific variation and uncertainty estimates available in ClimPlant.

\section{4 | DISCUSSION}

The ClimPlant database fills an essential knowledge gap in the study of climate change impacts in temperate European forests. The database provides climatic niche estimates for nearly 1,000 plant species representing a large part of the temperate European forest flora. The realized climatic niche data from ClimPlant are correlated with existing categorical indicator values, such as the Ellenberg $T$-values, but are objective, transparent and data driven (BOX 1). They allow the incorporation of uncertainty in the climatic responses of species, increasing the robustness and opening up new possibilities for quantitative data analyses.

The realized climatic niches were inferred from atlas distribution maps with a limited spatial resolution. Hence, those distribution ranges reflect the extent of occurrence rather than the area of occupancy, which includes only areas where the species genuinely appears (Gaston \& Fuller, 2009; Sheth et al., 2020). The distributions also include smaller unsuitable habitats, such as urban
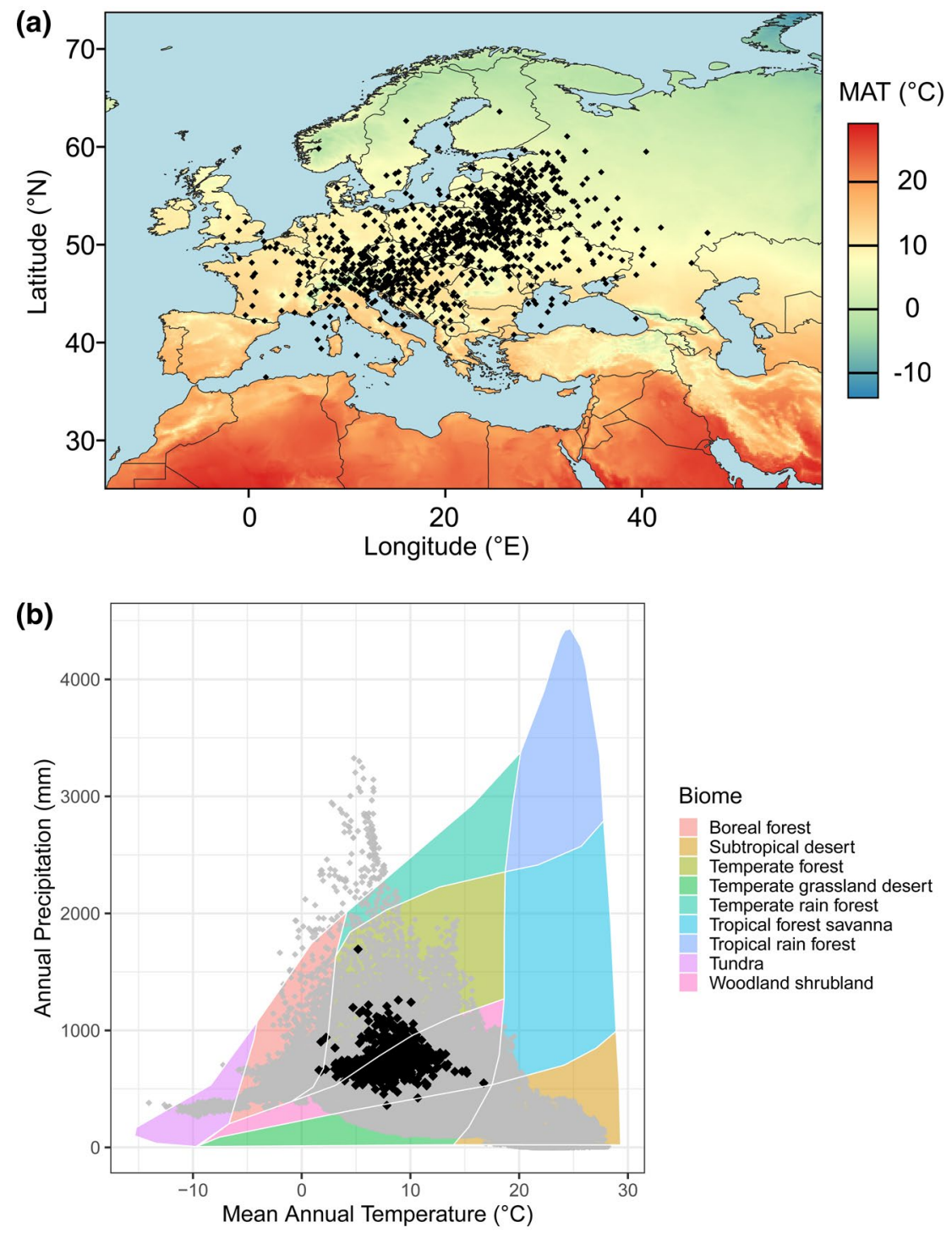

FIGURE 2 (a) Centroids of the distribution range within the study area of the 968 temperate forest species contained in the ClimPlant database, with the 1970-2000 mean annual temperature (MAT; in degrees Celsius) as background raster. The map was made with QGIS (QGIS Development Team, 2020). (b) The 1970-2000 mean annual temperature (in degrees Celsius) and annual precipitation (in millimetres) of every grid cell in the study area (grey) and the mean annual temperature (in degrees Celsius) and mean annual precipitation (in millimetres) across the distribution range of the 968 temperate forest species (black), plotted on Whittaker's biomes (Ricklefs, 2008; as obtained from Kunstler, 2014). [Colour figure can be viewed at wileyonlinelibrary. com] 
BOX 1 Strengths and limitations of the ClimPlant database

\section{Major strengths}

- Realized climatic niches are derived from expert-based, natural distribution ranges where plants have persisted within the studied time frame.

- Estimated climatic niches are calculated through objective, transparent protocols and incorporate the full distribution of climatic profiles, thus increasing the robustness and opening new possibilities for quantitative data analyses.

- Data are already available for 968 vascular plant species, capturing a large part of the diversity in European forests; they are perfectly suited to determine floristic temperatures of plant communities.

\section{Major limitations}

- ClimPlant provides estimates of species' climatic tolerances based on realized niches, which might differ from physiological tolerances, owing to factors such as dispersal limitation, competition, herbivory and disease.

- Estimated niches are based on distribution and climate data with coarse spatial resolution, not reflecting microclimatic conditions.

- Climatic niche estimates are uncertain and should be used with caution.

areas. Nonetheless, larger discontinuities in the distribution range, such as absence in mountain regions, are often mapped correctly (e.g., absence of Ruscus aculeatus in the Pyrenees; Figure 1a). If suitable data on the area of occupancy of plant species were available at the continental scale, this would be a great improvement for species distribution modelling, because it would be possible to link the presence of a species to local attributes, such as microclimate and co-occurrence with other species. However, we still lack such data for most European plants. The ongoing Atlas Florae Europaea covers c. 25\% of the European flora from a few families so far, at a resolution of c. $50 \mathrm{~km} \times 50 \mathrm{~km}$ (Lahti \& Lampinen, 1999). Point-based observations (such as those provided by GBIF; GBIF.org, 2020) are another common source of distribution data. Nevertheless, these databases are still incomplete for many species, have issues with misidentifications and are often geographically biased (e.g., data-deficient regions, such as eastern Europe and northern Africa) (Boakes et al., 2010; Lozier et al., 2009; Meyer et al., 2016), which can lead to important biases in the inferred climatic tolerances. Moreover, point-based observational data also often include records in areas outside the natural distribution range; for instance, owing to anthropogenic introductions in artificial conditions where the species will not manage to persist without human assistance. Hence, in order to infer plant climatic niches at a continental scale at present, it seems more sensible to rely on robust atlas distribution maps, as was done to develop the ClimPlant database (De Frenne et al., 2014; Fourcade, 2016).

The ClimPlant database builds on the relationship between climatic tolerance and the current species distribution. Climate is an important driver of species distributions (Gaston, 2003; Woodward, 1987), particularly at large spatio-temporal scales (Pearson \& Dawson, 2003; Peterson et al., 2011; Schweiger \& Beierkuhnlein, 2016), but it is not the only one. Other non-climatic factors, such as land use (history), dispersal limitation or biotic interactions, can condition the assumed equilibrium of species distribution with climate (Silvertown, 2004; Peterson et al., 2011), potentially resulting in a difference between the realized climatic niche and the fundamental climatic niche. The ClimPlant database should, therefore, be used with care, acknowledging the uncertainties inherent to such distribution-based climatic tolerance estimates (Araújo \& Peterson, 2012; Bahn \& McGill, 2007; Fourcade et al., 2018; Journé et al., 2020). The uncertainty and risk of bias might be inversely related to range size (Bocsi et al., 2016); therefore, increased caution should be exercised regarding species with small distribution ranges (range size is included as a variable in ClimPlant and could be used to filter out species with small ranges). Attempts to extrapolate these climatic tolerances into new areas or time frames (e.g., with correlative species distribution models; Journé et al., 2020) are particularly risky and are likely to require more sophisticated approaches involving multivariable models (Briscoe et al., 2019). Nonetheless, there are many legitimate research questions for which we are lacking basic information on species tolerances or, simply put, the types of climate that species inhabit. By providing a statistical distribution of climatic values across species ranges, the ClimPlant database represents a step forwards in that regard, particularly in comparison to the use of simple indicator values with no associated uncertainty (Rodríguez-Sánchez et al., 2012).

ClimPlant can be instrumental in assessments of climate change impact and to advance our understanding of species ranges and community dynamics. These data can, for instance, be used to quantify species reshuffling, to assess the degree of "thermophilization" of plant communities driven by climate warming (De Frenne et al., 2013; Zellweger et al., 2020), or to investigate the relationship between distribution range and vulnerability to global change (Staude et al., 2020). The ClimPlant database is conceived as a dynamic database, because we plan to extend it with additional species and update it when more or better maps become available, including forest microclimate maps when available at the European scale (e.g., Lembrechts et al., 2020). As such, the ClimPlant database will be a significant step forwards for the modelling of vegetation in the face of global climate change.

\section{ACKNOWLEDGMENTS}

The authors thank Aneta Lukačevičová, Jonas Pieters, Silvie Suchánková, Martina Sychrová and Matej Tabačák for the help with the digitization of a part of the distribution maps. P.V. and P.D.F. were 
financially supported by the European Research Council through the FORMICA project (ERC starting grant no. 757833). F.R.-S. was supported by the European Union Seventh Framework Programme FP7/2007-2013 (grant no. 275094) and the VI Plan Propio de Investigación of Universidad de Sevilla (VI PPIT - US). F.M. was supported by project APVV-19-0319, and M.C., R.H. and O.V. by the Czech Academy of Sciences long-term research development project RVO 67985939. The authors also thank editor Volker Bahn and two anonymous reviewers for constructive comments on a previous version of this manuscript.

\section{CONFLICT OF INTEREST}

The authors declare no conflict of interest.

\section{AUTHOR CONTRIBUTIONS}

P.V. and P.D.F conceived and designed the study; all authors digitized distribution maps; P.V. performed the data analyses and wrote the manuscript with contributions from all authors.

\section{DATA AVAILABILITY STATEMENT}

The full dataset is accessible at: https://doi.org/10.6084/m9.figsh are.12199628

\section{ORCID}

Pieter Vangansbeke (iD https://orcid.org/0000-0002-6356-2858

František Máliš iD https://orcid.org/0000-0003-2760-6988

Radim Hédl (iD https://orcid.org/0000-0002-6040-8126

Markéta Chudomelová iD https://orcid.org/0000-0001-7845-4000

Ondřej Vild (iD https://orcid.org/0000-0002-0728-2392

Monika Wulf iD https://orcid.org/0000-0001-6499-0750

Erik Welk (iD https://orcid.org/0000-0002-2685-3795

Francisco Rodríguez-Sánchez iD https://orcid.

org/0000-0002-7981-1599

Pieter De Frenne iD https://orcid.org/0000-0002-8613-0943

\section{REFERENCES}

Araújo, M. B., \& Peterson, A. T. (2012). Uses and misuses of bioclimatic envelope modeling. Ecology, 93, 1527-1539. https://doi. org/10.1890/11-1930.1

Baeten, L., Warton, D. I., Van Calster, H., De Frenne, P., Verstraeten, G., Bonte, D., Bernhardt-Römermann, M., Cornelis, J., Decocq, G., Eriksson, O., Hédl, R., Heinken, T., Hermy, M., Hommel, P., Kirby, K., Naaf, T., Petřík, P., Walther, G.-R., Wulf, M., \& Verheyen, K. (2014). A model-based approach to studying changes in compositional heterogeneity. Methods in Ecology and Evolution, 5, 156-164. https://doi. org/10.1111/2041-210X.12137

Bahn, V., \& McGill, B. J. (2007). Can niche-based distribution models outperform spatial interpolation? Global Ecology and Biogeography, 16 733-742. https://doi.org/10.1111/j.1466-8238.2007.00331.x

Bartelheimer, M., \& Poschlod, P. (2016). Functional characterizations of Ellenberg indicator values - a review on ecophysiological determinants. Functional Ecology, 30, 506-516. https://doi. org/10.1111/1365-2435.12531

Berg, C., Welk, E., \& Jäger, E. J. (2017). Revising Ellenberg's indicator values for continentality based on global vascular plant species distribution. Applied Vegetation Science, 20, 482-493. https://doi. org/10.1111/avsc.12306

Bernhardt-Römermann, M., Baeten, L., Craven, D., De Frenne, P., Hédl, R., Lenoir, J., Bert, D., Brunet, J., Chudomelová, M., Decocq, G., Dierschke, H., Dirnböck, T., Dörfler, I., Heinken, T., Hermy, M., Hommel, P., Jaroszewicz, B., Keczyński, A., Kelly, D. L., ... Verheyen, K. (2015). Drivers of temporal changes in temperate forest plant diversity vary across spatial scales. Global Change Biology, 21, 37263737. https://doi.org/10.1111/gcb.12993

Boakes, E. H., McGowan, P. J. K., Fuller, R. A., Chang-qing, D., Clark, N. E., O'Connor, K., \& Mace, G. M. (2010). Distorted views of biodiversity: Spatial and temporal bias in species occurrence data. PLoS Biology, 8, e1000385. https://doi.org/10.1371/journal.pbio.1000385

Bocsi, T., Allen, J. M., Bellemare, J., Kartesz, J., Nishino, M., \& Bradley, B. A. (2016). Plants' native distributions do not reflect climatic tolerance. Diversity and Distributions, 22, 615-624. https://doi. org/10.1111/ddi.12432

Briscoe, N. J., Elith, J., Salguero-Gómez, R., Lahoz-Monfort, J. J., Camac, J. S., Giljohann, K. M., Holden, M. H., Hradsky, B. A., Kearney, M. R., McMahon, S. M., Phillips, B. L., Regan, T. J., Rhodes, J. R., Vesk, P. A., Wintle, B. A., Yen, J. D. L., \& Guillera-Arroita, G. (2019). Forecasting species range dynamics with process-explicit models: Matching methods to applications. Ecology Letters, 22, 1940-1956. https://doi. org/10.1111/ele.13348

Broennimann, O., Thuiller, W., Hughes, G., Midgley, G. U. Y. F., Alkemade, J. M. R., \& Guisan, A. (2006). Do geographic distribution, niche property and life form explain plants' vulnerability to global change? Global Change Biology, 12, 1079-1093. https://doi. org/10.1111/j.1365-2486.2006.01157.x

Chen, I.-C., Hill, J. K., Ohlemüller, R., Roy, D. B., \& Thomas, C. D. (2011). Rapid range shifts of species associated with high levels of climate warming. Science, 333(6045), 1024-1026. https://doi.org/10.1126/ science.1206432

De Frenne, P., Rodríguez-Sánchez, F., Bernhardt-Römermann, M., Brown, C. D., Eriksson, O., Hermy, M., Mitchell, F. J. G., Petřík, P., Van Calster, H., Vellend, M., \& Verheyen, K. (2014). Reply to Harwood et al.: Thermophilization estimation is robust to the scale of species distribution data. Proceedings of the National Academy of Sciences USA, 111, E1166. https://doi.org/10.1073/pnas.1401414111

De Frenne, P., Rodriguez-Sanchez, F., Coomes, D. A., Baeten, L., Verstraeten, G., Vellend, M., Bernhardt-Romermann, M., Brown, C. D., Brunet, J., Cornelis, J., Decocq, G. M., Dierschke, H., Eriksson, O. Gilliam, F. S., Hedl, R., Heinken, T., Hermy, M., Hommel, P., Jenkins, M. A., ... Verheyen, K. (2013). Microclimate moderates plant responses to macroclimate warming. Proceedings of the National Academy of Sciences USA, 110, 18561-18565. https://doi.org/10.1073/ PNAS.1311190110

De Frenne, P., Rodríguez-Sánchez, F., De Schrijver, A. N., Coomes, D. A., Hermy, M., Vangansbeke, P., \& Verheyen, K. (2015). Light accelerates plant responses to warming. Nature Plants, 1(9), 15110. https://doi. org/10.1038/nplants.2015.110

De Frenne, P., Zellweger, F., Rodríguez-Sánchez, F., Scheffers, B. R., Hylander, K., Luoto, M., Vellend, M., Verheyen, K., \& Lenoir, J. (2019). Global buffering of temperatures under forest canopies. Nature Ecology \& Evolution, 3, 744-749. https://doi.org/10.1038/s4155 9-019-0842-1

Diekmann, M. (2003). Species indicator values as an important tool in applied plant ecology - A review. Basic and Applied Ecology, 4, 493-506. https://doi.org/10.1078/1439-1791-00185

Ellenberg, H., \& Leuschner, C. (2010). Vegetation Mitteleuropas mit den Alpen: In Ökologischer, dynamischer and historischer Sicht (6 ed.), Ulmer.

Euro+Med. (2006). Euro+Med PlantBase - the information resource for Euro-Mediterranean plant diversity. Retrieved 1 March 2019. http:// www.emplantbase.org/home.html 
Fick, S. E., \& Hijmans, R. J. (2017). WorldClim 2: New 1-km spatial resolution climate surfaces for global land areas. International Journal of Climatology, 37, 4302-4315. https://doi.org/10.1002/joc.5086

Fourcade, Y. (2016). Comparing species distributions modelled from occurrence data and from expert-based range maps. Implication for predicting range shifts with climate change. Ecological Informatics, 36, 8-14. https://doi.org/10.1016/j.ecoinf.2016.09.002

Fourcade, Y., Besnard, A. G., \& Secondi, J. (2018). Paintings predict the distribution of species, or the challenge of selecting environmental predictors and evaluation statistics. Global Ecology and Biogeography, 27, 245-256. https://doi.org/10.1111/geb.12684

Gaston, K. J. (2003). The structure and dynamics of geographic ranges. Oxford University Press.

Gaston, K. J., \& Fuller, R. A. (2009). The sizes of species' geographic ranges. Journal of Applied Ecology, 46, 1-9. https://doi. org/10.1111/j.1365-2664.2008.01596.x

GBIF.org. (2020). GBIF occurrence download. https://www.gbif.org/

Gilliam, F. S. (2007). The ecological significance of the herbaceous layer in temperate forest ecosystems. BioScience, 57, 845-858. https://doi. org/10.1641/B571007

Gilliam, F. S. (2016). Forest ecosystems of temperate climatic regions: From ancient use to climate change. New Phytologist, 212, 871-887. https://doi.org/10.1111/nph.14255

Hultén, E., \& Fries, M. (1986). Atlas of North European vascular plants: North of the Tropic of Cancer. Koeltz Scientific.

Journé, V., Barnagaud, J., Bernard, C., Crochet, P., \& Morin, X. (2020). Correlative climatic niche models predict real and virtual species distributions equally well. Ecology, 101, e02912. https://doi. org/10.1002/ecy.2912

Kunstler, G. (2014). BIOMEplot: Plot the Whittaker biomes. R package version 0.1. https://github.com/kunstler/BIOMEplot

Lahti, T., \& Lampinen, R. (1999). From dots to bitmaps: Atlas Florae Europaeae goes digital. Acta Botanica Fennica, 162, 5-9.

Lembrechts, J. J., Aalto, J., Ashcroft, M. B., De Frenne, P., Kopecký, M., Lenoir, J., Luoto, M., Maclean, I. M. D., Roupsard, O., Fuentes-Lillo, E., García, R. A., Pellissier, L., Pitteloud, C., Alatalo, J. M., Smith, S. W., Björk, R. G., Muffler, L., Ratier Backes, A., Cesarz, S., ... Nijs, I. (2020). SoilTemp: A global database of near-surface temperature. Global Change Biology, 26, 6616-6629. https://doi.org/10.1111/gcb.15123

Lenoir, J., \& Svenning, J.-C. (2015). Climate-related range shifts - a global multidimensional synthesis and new research directions. Ecography, 38, 15-28. https://doi.org/10.1111/ecog.00967

Lozier, J. D., Aniello, P., \& Hickerson, M. J. (2009). Predicting the distribution of Sasquatch in western North America: Anything goes with ecological niche modelling. Journal of Biogeography, 36, 1623-1627. https://doi.org/10.1111/j.1365-2699.2009.02152.x

Maclean, I. M. D. (2020). Predicting future climate at high spatial and temporal resolution. Global Change Biology, 26, 1003-1011. https:// doi.org/10.1111/gcb.14876

Meusel, H., Jäger, E. J., \& Weinert, E. (1965). Vergleichende Chorologie der zentraleuropaischen Flora, Karten, Vol. I. VEB Gustav Fischer.

Meusel, H., Jäger, E. J., Rauschert, S., \& Weinert, E. (1978). Vergleichende Chorologie der zentraleuropäischen Flora, Karten, Vol. II. VEB Gustav Fischer.

Meusel, H., \& Jäger, E. J. (1992). Vergleichende Chorologie der zentraleuropäischen Flora, Karten, Vol. III. VEB Gustav Fischer.

Meyer, C., Weigelt, P., \& Kreft, H. (2016). Multidimensional biases, gaps and uncertainties in global plant occurrence information. Ecology Letters, 19, 992-1006. https://doi.org/10.1111/ele.12624

Pearman, P. B., Guisan, A., Broennimann, O., \& Randin, C. F. (2008). Niche dynamics in space and time. Trends in Ecology and Evolution, 23, 149-158. https://doi.org/10.1016/j.tree.2007.11.005

Pearson, R. G., \& Dawson, T. P. (2003). Predicting the impacts of climate change on the distribution of species: Are bioclimate envelope models useful? Global Ecology and Biogeography, 12, 361-371. https:// doi.org/10.1046/j.1466-822X.2003.00042.x

Pecl, G. T., Araújo, M. B., Bell, J. D., Blanchard, J., Bonebrake, T. C., Chen, I.-C., Clark, T. D., Colwell, R. K., Danielsen, F., Evengård, B., Falconi, L., Ferrier, S., Frusher, S., Garcia, R. A., Griffis, R. B., Hobday, A. J., Janion-Scheepers, C., Jarzyna, M. A., Jennings, S., ... Williams, S. E. (2017). Biodiversity redistribution under climate change: Impacts on ecosystems and human well-being. Science, 355(6332), eaai9214. https://doi.org/10.1126/science.aai9214

Pellissier, L., Bråthen, K. A., Vittoz, P., Yoccoz, N. G., Dubuis, A., Meier, E. S., Zimmermann, N. E., Randin, C. F., Thuiller, W., Garraud, L., Van Es, J., \& Guisan, A. (2013). Thermal niches are more conserved at cold than warm limits in arctic-alpine plant species. Global Ecology and Biogeography, 22, 933-941. https://doi.org/10.1111/geb.12057

Peterson, A., Soberón, J., Pearson, G., Anderson, R., Martínez-Meyer, E., Nakamura, M., \& Araújo, M. (2011). Ecological niches and geographic distributions. In Monographs in population biology (Vol. 49). Princeton University Press.

QGIS Development Team. (2020). QGIS geographic information system. Open source Geospatial Foundation project. http://qgis.osgeo.org

R Core Team. (2020). R: A language and environment for statistical computing. R Foundation for Statistical Computing. https://www.r-proje ct.org

Ricklefs, R. E. (2008). Chapter 5, The biome concept in ecology. In The economy of nature (6 ed., pp. 87-112). W.H. Freeman and Company.

Rodríguez-Sánchez, F., De Frenne, P., \& Hampe, A. (2012). Uncertainty in thermal tolerances and climatic debt. Nature Climate Change, 2, 636637. https://doi.org/10.1038/nclimate1667

Schweiger, A. H., \& Beierkuhnlein, C. (2016). Scale dependence of temperature as an abiotic driver of species' distributions. Global Ecology and Biogeography, 25, 1013-1021. https://doi.org/10.1111/ geb.12463

Sheth, S. N., Morueta-Holme, N., \& Angert, A. L. (2020). Determinants of geographic range size in plants. New Phytologist, 226, 650-665. https://doi.org/10.1111/nph.16406

Silvertown, J. (2004). Plant coexistence and the niche. Trends in Ecology and Evolution, 19, 605-611. https://doi.org/10.1016/j. tree.2004.09.003

Soberón, J., \& Arroyo-Peña, B. (2017). Are fundamental niches larger than the realized? Testing a 50 -year-old prediction by Hutchinson. PLoS One, 12, e0175138. https://doi.org/10.1371/journal.pone.0175138

Staude, I. R., Waller, D. M., Bernhardt-Römermann, M., Bjorkman, A. D., Brunet, J., De Frenne, P., \& Baeten, L. (2020). Replacements of smallby large-ranged species scale to diversity loss in Europe's temperate forest biome. Nature Ecology \& Evolution, 4, 802-808. https://doi. org/10.1038/s41559-020-1176-8

Urban, M. C. (2015). Accelerating extinction risk from climate change. Science, 348(6234), 571-573. https://doi.org/10.1126/science.aaa4984.

Verheyen, K., Baeten, L., De Frenne, P., Bernhardt-Römermann, M., Brunet, J., Cornelis, J., Decocq, G., Dierschke, H., Eriksson, O., Hédl, R., Heinken, T., Hermy, M., Hommel, P., Kirby, K., Naaf, T., Peterken, G., Petřík, P., Pfadenhauer, J., ... Verstraeten, G. (2012). Driving factors behind the eutrophication signal in understorey plant communities of deciduous temperate forests. Journal of Ecology, 100, 352365. https://doi.org/10.1111/j.1365-2745.2011.01928.x

Woodward, F. I. (1987). Climate and plant distribution. Cambridge University Press.

Zellweger, F., Coomes, D., Lenoir, J., Depauw, L., Maes, S. L., Wulf, M., Kirby, K. J., Brunet, J., Kopecký, M., Máliš, F., Schmidt, W., Heinrichs, S., den Ouden, J., Jaroszewicz, B., Buyse, G., Spicher, F., Verheyen, K., \& De Frenne, P. (2019). Seasonal drivers of understorey temperature buffering in temperate deciduous forests across Europe. Global Ecology and Biogeography, 28, 1774-1786. https://doi.org/10.1111/ geb.12991 
Zellweger, F., De Frenne, P., Lenoir, J., Vangansbeke, P., Verheyen, K., Bernhardt-Römermann, M., \& Coomes, D. (2020). Forest microclimate feedbacks drive plant responses to warming. Science, 368(6492), 772-775. https://doi.org/10.1126/SCIENCE.ABA6880

\section{BIOSKETCH}

We are a group of researchers focusing on the impact of global change on plant communities and ecosystem functioning in the understorey of temperate European forests at different spatiotemporal scales.

\section{SUPPORTING INFORMATION}

Additional Supporting Information may be found online in the Supporting Information section.

How to cite this article: Vangansbeke P, Máliš F, Hédl R, et al. ClimPlant: Realized climatic niches of vascular plants in European forest understoreys. Global Ecol Biogeogr. 2021;30:1183-1190. https://doi.org/10.1111/geb.13303 